\title{
Implementasi Metode Metaheuristik Symbiotic Organisms Search dalam Penentuan Tata Letak Fasilitas Proyek Konstruksi Berdasarkan Jarak Tempuh Pekerja
}

\author{
Doddy Prayogo ${ }^{*}$, Richard Antoni Gosno ${ }^{1}$, Richard Evander ${ }^{1}$, Sentosa Limanto ${ }^{1}$
}

\begin{abstract}
This research investigates the performance of a new metaheuristic method called symbiotic organisms search (SOS) for solving the site layout of construction project facilities based on travelling distance. Two practical case studies of facility layout are used to examine the accuracy and consistency of the proposed algorithm. Additionally, three other metaheuristic methods, called particle swarm optimization, artificial bee colony, and teaching-learning-based optimization, are employed as a comparison to the SOS algorithm. The simulation results indicate the superiority of the SOS as well as excellent convergence behavior over the other methods in optimizing the site layout of construction facilities.
\end{abstract}

Keywords: Facility layout, optimization, metaheuristic, symbiotic organisms search.

\section{Pendahuluan}

Penentuan tata letak fasilitas merupakan kunci utama dalam dunia konstruksi dan harus dipertimbangkan sedini mungkin terutama dalam tahap perencanaan. Tujuan utama penentuan tata letak fasilitas adalah untuk mengatur seefisien mungkin letak fasilitas-fasilitas sementara seperti kantor, tempat tinggal pekerja, tempat penyimpanan barang, dan lain-lain, sehingga aktivitas pekerjaan dapat dilakukan lebih leluasa dengan biaya seminimal mungkin. Tata letak fasilitas yang baik sangat penting untuk meningkatkan efektivitas kerja serta meminimalkan jarak tempuh pekerja proyek, terutama pada proyek yang berskala cukup besar (Adrian et al. [1]). Umumnya, manajer proyek cenderung menggunakan intuisi dan pengalaman kerja proyek sebelumnya sebagai acuan untuk melakukan merencanakan letak fasilitas proyek. Namun, hal ini tidak menjamin terwujudnya suatu perencanaan tata letak fasilitas proyek yang optimal (Tommelein et al. [2]. Hal ini mendorong para peneliti untuk menciptakan sejumlah metode yang berpotensi untuk menghasilkan tata letak fasilitas yang efisien.

Banyak studi yang telah dilakukan untuk mengembangkan metode optimasi untuk menyelesaikan proproblem tata letak fasilitas. Beberapa pendekatan matematis dan heuristic telah dikembangkan di awal untuk menyelesaikan problem tersebut, diantaranya branch-and-bound (Simmons [3]), dynamic programming (Picard dan Queyranne [4]), and integer linear programming (Love dan Wong [5]). Setelah itu, Ravi et al. [6] memperkenalkan metode heuristik untuk menyelesaikan salah satu permasalahan tata letak fasilitas.

\footnotetext{
${ }^{1}$ Fakultas Teknik Sipil dan Perencanaan, Program Studi Teknik Sipil, Universitas Kristen Petra, J. Siwalankerto 121-131, Surabaya 60238, Indonesia.

Email: prayogo@petra.ac.id,m21413042@john.petra.ac.id, m21413048@john.petra.ac.id,leonard@petra.ac.id.

* Penulis korespondensi
}

Namun, pendekatan matematis ini seringkali tidak cukup untuk menyelesaikan problem-problem berskala besar sedangkan metode pencarian heuristik seringkali mengalami kendala pada rendahnya kualitas solusi yang dihasilkan akibat terjebak pada local optima. Hal ini mendorong meningkatnya upaya-upaya untuk mengembangkan metode-metode optimasi yang lebih akurat dan efisien.

Dalam beberapa tahun terakhir, penggunaan algoritma metaheuristik semakin meningkat bila dibandingkan dengan metode konvensional berbasis matematis karena performanya yang sudah teruji dalam menyelesaikan berbagai macam masalah optimasi yang rumit. Algoritma metaheurisitik memiliki skema pencarian solusi yang terinspirasi dari prinsip-prinsip alamiah yang dikembangkan oleh makhluk hidup, antara lain: evolusi dan seleksi alam yang diadopsi oleh genetic algorithm (GA, Holland [7]); interaksi sosial dari sekawanan ikan maupun burung yang ditiru oleh particle swarm optimization (PSO, Kennedy dan Eberhart [8]; maupun interaksi koloni semut untuk menemukan sumber makanan yang menginspirasi ant colony optimization (ACO, Dorigo et al. [9]. Salah satu keuntungan algoritma metaheuristik dibandingkan dengan metode optimasi lain adalah mayoritas skema pencariannya mengijinkan diterimanya solusi yang kurang optimal yang membuat cakupan pencarian solusi menjadi lebih luas yang dapat berujung pada penemuan solusi yang lebih baik. Di sisi lain, algoritma metaheuristik juga dapat menghasilkan kualitas solusi yang cukup baik dengan waktu pencarian yang cenderung relatif cepat.

Berkembangnya penelitian ini memacu munculnya banyak penerapan metode metaheuristik untuk menyelesaikan kasus-kasus optimasi tata letak fasilitas. Li dan Love [10] menggunakan GA untuk mengoptimasi tata letak 11 buah fasilitas. Hasil 
eksperimen menunjukkan bahwa GA mampu menghasilkan solusi yang cukup baik dengan jumlah iterasi yang relatif sedikit, yaitu kurang dari 100 iterasi. Zouein et al. [11] juga menggunakan GA dalam mengoptimasi tata letak fasilitas proyek dengan tambahan pembatas geometris. Lee et al. [12] mengimprovisasi GA untuk menyelesaikan permasalahan tata letak yang fasilitas yang ditempatkan di berbagai macam lantai yang memiliki tambahan batasan berupa dinding dan lorong. Önüt et al. [13] menggunakan PSO untuk mencari tata letak fasilitas gudang. Zhang dan Wang [14] mengadopsi PSO untuk menemukan tata letak fasilitas proyek konstruksi yang optimal. Hasil simulasi dari PSO kemudian dibandingkan dengan hasil dari GA, di mana PSO mampu menghasilkan solusi yang lebih optimal dengan jumlah iterasi yang lebih sedikit. Lam et al.[15] memperkenalkan ACO untuk menyelesaikan tata letak 13 fasilitas sementara proyek konstruksi. Dari hasil eksperimen, ditunjukkan bahwa ada penghematan biaya sebesar 6,3\% 10,8\% dari biaya semula. Tabu search (TS) digunakan oleh Liang dan Chao [16] untuk problem tata letak fasilitas yang didasarkan terhadap aliran sumber daya dari fasilitas dan hubungan terhadap fasilitas yang berdekatan. Yahya dan Saka [17] mengenalkan artificial bee colony (ABC) untuk problem tata letak fasilitas yang harus dioptimasi dengan mempertimbangkan 2 buah fungsi objektif yaitu biaya handling serta factor keamanan dan lingkungan. Disamping itu, metode metaheuristik hibrida (Setiawan dan Palit [18]) juga dikembangkan guna mendapatkan solusi tata letak fasilitas yang lebih optimal. Seiring dengan meningkatnya kerumitan dari suatu proyek konstruksi, jumlah fasilitas pendukung sementara yang dibutuhkan cenderung ikut meningkat (Mak et al. [19]). Kompleksitas dari masalah tata letak fasilitas akan meningkat secara eksponensial seiring dengan bertambah banyaknya jumlah fasilitas. Sebagai contoh, kemungkinan alternatif solusi yang tersedia untuk 10 fasilitas adalah 10!, setara dengan 3.628.000. Hal ini menyebabkan diperlukannya pengembangan metode optimasi yang lebih maju untuk mengatasi kompleksitas dari masalah tata letak fasilitas.

Baru-baru ini, algoritma metaheuristik baru bernama symbiotic organisms search (SOS, Prayogo [20], Cheng et al. [21]) menarik perhatian para peneliti karena kemampuannya yang terbukti cukup baik dalam menyelesaikan berbagai permasalahan optimasi yang kompleks dalam berbagai macam bidang [22-26]. SOS mengadopsi pola interaksi simbiosis yang umum ditemukan antar makhluk hidup. Dalam mempertahankan kelangsungan hidupnya, makhluk hidup akan berinteraksi dengan makhluk hidup lainnya dalam bentuk simbiosis. Melalui interaksi itulah makhluk hidup dapat meningkatkan kualitas hidupnya untuk dapat bertahan hidup. Terinspirasi oleh fenomena simbiosis ini, algoritma SOS menggunakan tiga fase utama yaitu mutualism, commensalism, dan parasitism, untuk menemukan solusi terbaik secara efektif dan efisien.

Keberhasilan penerapan SOS sebelumnya pada berbagai masalah optimasi yang rumit melatar belakangi investigasi lebih lanjut terhadap kemampuan algoritma ini optimasi tata letak fasilitas proyek dengan meninjau traveling distance minimum dari pekerja. Studi komparatif akan dilakukan dengan membandingkan kinerja SOS dan metode metaheuristik lainnya, yaitu PSO, ABC, dan teaching-learning-based optimization (TLBO). Selain menggunakan studi kasus benchmark, penelitian ini juga menggunakan studi kasus baru yang dikembangkan dari salah satu proyek konstruksi bangunan bertingkat di Surabaya.

\section{Metode Penelitian}

\section{Perumusan Masalah Optimasi Tata Letak Fasilitas Proyek Konstruksi}

Perencanaan tata letak fasilitas terdiri dari beberapa proses diantara lain mengindentifikasi fasilitasfasilitas yang dibutuhkan untuk mendukung pelaksanaan konstruksi, menentukan dimensi serta bentuk fasilitas, dan menempatkan fasilitas-fasilitas tersebut dalam suatu ruang terbatas yang tersedia dalam area proyek [2]. Untuk dapat menghasilkan penempatan fasilitas-fasilitas sementara yang efisien, maka perlu dilakukan optimasi pada perencanaan tata letak fasilitas. Pada umumnya, optimasi tata letak fasilitas proyek konstruksi dilakukan untuk mencari penempatan lokasi fasilitas sementara yang menghasilkan biaya termurah. Terdapat beberapa faktor pembatas pada permasalahan tata letak fasilitas, yaitu sejumlah $m$ fasilitas harus diposisikan pada sejumlah $n$ lokasi pada suatu site proyek, dimana $n \geq m$.

Pada penelitian ini, tujuan dari perencanaan tata letak fasilitas adalah untuk meminimalkan jarak tempuh pekerja proyek konstruksi antar fasilitas. Penelitian ini menggunakan asumsi setiap lokasi harus ditugaskan hanya dengan satu fasilitas, dan setiap fasilitas harus ditugaskan di satu lokasi saja. Problem optimasi tata letak fasilitas dapat diformulasikan sebagai quadratric assignment problem [27, 28] sebagai berikut.

Minimum $T D=\sum_{i=1}^{n} \sum_{j=1}^{n} \sum_{k=1}^{n} \sum_{l=1}^{n} f_{i k} d_{j l} x_{i j} x_{k l}$
Kendala
$\sum_{j=1}^{n} x_{i j}=1, i=1, \ldots, n$
$\sum_{i=1}^{n} x_{i j}=1, j=1, \ldots, n$
$x \in\{0,1\}, i, j=1, \ldots, n$
dimana $n$ adalah jumlah fasilitas, $x_{i j}$ adalah variabel 
penugasan $\left(x_{i j}=1\right.$ jika fasilitas $i$ ditugaskan ke lokasi $j$, dan $x_{i j}=0$ lainnya). $f_{i k}$ adalah frekuensi perpindahan dalam satu satuan waktu yang dilakukan oleh pekerja proyek konstruksi antara fasilitas $i$ dan $k$. Dalam penelitian ini satuan waktu yang digunakan adalah satu hari. $d_{j l}$ adalah jarak antara lokasi $j$ dan $l$. Apabila kedua lokasi berada di samping satu sama lain, jaraknya didefinisikan sebagai jarak antara pusat kedua lokasi; jika tidak, maka jaraknya didefinisikan sebagai sejumlah jarak segmental fasilitas-fasilitas yang ada di antara keduanya (sebagai contoh, $d_{13}$ merupakan total jarak $d_{12}$ dan $d_{23}$ ).

Pada penelitian ini, metode metaheuristik yang digunakan dalam proses optimasi akan dijabarkan lebih lanjut. Semua algoritma yang digunakan di sini merupakan algoritma continuous berbasis multi-agent. Algoritma-algoritma ini memulai proses optimasi dengan satu set alternatif solusi dari problem tersebut dan akan berusaha untuk meningkatkan kualitas dari alternatif solusi tersebut berdasarkan dari fungsi objektif yang diketahui. Berdasarkan serangkaian aturan yang sederhana yang sebagian besar terinspirasi dari alam, algoritma metaheuristik akan memodifikasi solusi yang sudah ada secara iterative dengan tujuan untuk meningkatkan nilai objektif mereka. Bagian selanjutnya akan menjabarkan secara singkat metode SOS bersamaan dengan tiga metode pembanding lainnya yaitu PSO, ABC, dan TLBO.

\section{Symbiotic Organisms Search (SOS)}

Algoritma SOS pertama kali diperkenalkan oleh Cheng dan Prayogo [21] untuk menyelesaikan problem berbasis continuous. SOS merupakan salah satu algoritma metaheuristik yang mensimulasikan interaksi-interaksi simbiosis yang berbeda-beda yang dilakukan oleh sepasang organisme didalam suatu ekosistem. Interaksi antar organisme dimana masing-masing organisme mendapatkan keuntungan disebut dengan simbiosis mutualisme. Interaksi antar organisme dimana ada satu organisme yang diuntungkan sedangkan yang lainnya netral dikenal sebagai simbiosis komensalisme. Interaksi antar organisme dimana ada satu organisme yang diuntungkan sedangkan yang lainnya dirugikan disebut dengan simbiosis parasitisme. Ketiga macam interaksi simbiosis ini, seperti yang terlihat pada Gambar 1, menginspirasi proses optimasi dari algoritma SOS.

Berbeda dari GA dan metaheuristik berbasis evolutionary algorithm, SOS tidak memproduksi atau menciptakan keturunan. Namun, layaknya algoritma yang berbasis populasi, SOS menciptakan sebuah populasi mula-mula (yang disebut dengan ekosistem) dan akan melalui berbagai operator pencarian yang secara iteratif akan mencoba untuk

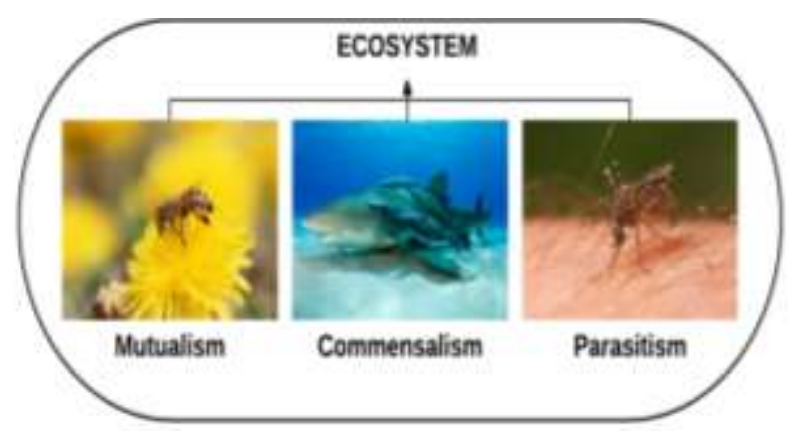

Gambar 1. Ilustrasi simbiosis yang terjadi antar makhluk hidup

memodifikasi populasi untuk menghasilkan variabel solusi (yang disebut dengan organisme) yang optimal.

Operator pencarian dari algoritma SOS terdiri atas tiga jenis, yaitu: mutualism phase, commensalism phase, dan parasitism phase. Uraian mengenai ketiga fase yang disebutkan sebelumnya dijabarkan melalui sub-bab berikut ini.

\section{Mutualism Phase}

Pada fase ini, organisme ke- $i$ di dalam ekosistem, $O_{i}$, akan berinteraksi secara mutualisme dengan organisme lain yang dipilih secara acak, $O_{j}$, dengan tujuan untuk peningkatan kualitas hidup masingmasing di ekosistem. Selanjutnya, dua variabel solusi, $n e w_{-} O_{i}$ dan $n e w_{-} O_{j}$ akan diciptakan melalui hasil modifikasi setelah simbiosis mutualisme dilakukan yang dimodelkan dengan operasi matematis pada Persamaan (5) dan (6) yang juga melibatkan $O_{\text {best }}$, organisme dengan nilai objektif terbaik dalam ekosistem. Apabila nilai objektif dari kandidat solusi $n e w_{-} O_{i}$ dan $n e w_{-} O_{j}$ hasil modifikasi $O_{i}$ dan $O_{j}$ lebih optimal daripada sebelumnya, organisme $O_{i}$ dan $O_{j}$ akan diperbarui.

$$
\begin{aligned}
& \operatorname{new}_{O_{i}}=O_{i}+\operatorname{rand}(0,1) * \\
& \left(O_{\text {best }}-\left[\operatorname{average}\left(O_{i}, O_{j}\right)\right] * \operatorname{round}[1+\operatorname{rand}(0,1)]\right) \\
& \operatorname{new}_{O_{j}}=O_{j}+\operatorname{rand}(0,1) * \\
& \left(O_{\text {best }}-\left[\operatorname{average}\left(O_{i}, O_{j}\right)\right] * \operatorname{round}[1+\operatorname{rand}(0,1)]\right)
\end{aligned}
$$

\section{Commensalism Phase}

Pada fase ini, organisme $O_{i}$ akan berinteraksi secara komensalisme dengan organisme lain yang dipilih secara acak, $O_{j}$. Kali ini, organisme $O_{i}$ mengambil keuntungan dari interaksi dengan organisme $O_{j}$ namun organisme $O_{j}$ sendiri tidak diuntungkan maupun dirugikan. Variabel solusi $n e w_{-} O_{i}$ diciptakan melalui hasil modifikasi setelah simbiosis komensalisme dilakukan yang dimodelkan dengan operasi matematis Persamaan (7). Apabila nilai objektif dari kandidat solusi $n e w_{-} O_{i}$ hasil modifikasi 
$O_{i}$ lebih optimal daripada sebelumnya, organisme $O_{i}$ akan diperbarui.

new_ $O_{i}=O_{i}+\operatorname{rand}(-1,1) *\left(O_{\text {best }}-O_{j}\right)$

\section{Parasitism Phase}

Fase ini digambarkan melalui hubungan antara nyamuk anopheles yang menyebarkan parasit plasmodium ke dalam tubuh inangnya yaitu manusia. Parasit mengambil keuntungan dari hubungannya dengan manusia karena dapat berkembang biak di dalam inangnya. Di sisi lain, manusia dirugikan oleh penyakit malaria yang dibawa melalu parasit tersebut. Fase ini dimulai dengan organisme $O_{i}$ yang memproduksi parasit buatan bernama "Parasite_Vector". Variabel solusi Parasite_Vector tersusun dari hasil perpaduan antara kloning terhadap organisme $O_{i}$ dan variabel acak. Organisme $O_{j}$, yang berfungsi sebagai inang, dipilih secara acak dari ekosistem. Evaluasi terhadap nilai objektif akan dilakukan terhadap Parasite_Vector dan $O_{j}$. Parasite_Vector akan menggantikan posisi organisme $O_{j}$ di ekosistem hanya jika nilai objektifnya lebih baik. Sebaliknya, $O_{j}$ akan bertahan dari Parasite_Vector bila nilai objektifnya lebih baik.

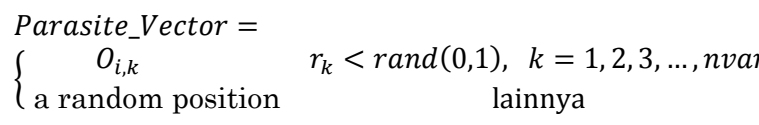

di mana nvar merupakan jumlah elemen dalam variabel solusi, $O_{i, k}$ menunjukkan nilai variabel dari elemen ke- $k$ dari organisme ke-i dalam ekosistem.

Pada masing-masing operator, para organisme yang ada didalam ekosistem akan berinteraksi secara acak antar satu dengan yang lain. Secara garis besar, algoritma SOS dapat dijabarkan seperti yang terlihat pada Gambar 2.

\section{Particle Swarm Optimization (PSO), Artificial Bee Colony (ABC), dan Teaching-Learning- Based Optimization (TLBO)}

Dikembangkan pertama kali oleh Kennedy dan Eberhart [8], PSO merupakan salah satu metode optimasi metaheuristik tertua yang mengadopsi prinsip swarm intelligence atau kecerdasan sosial berkelompok antar makhluk hidup. Mulanya, partikel-partikel akan diciptakan tersebar secara acak dalam lokasi pencarian. Posisi dari partikel-partikel tersebut melambangkan variabel solusi pada problem. Dalam setiap iterasi, partikel-partikel ini akan bergerak sesuai dengan vektor kecepatan dan akan selalu diperbaharui melalui suatu operator matematis yang memodelkan hubungan sosial berkelompok dari grup tersebut seperti yang ditunjukkan dalam Persamaan (9). Bilamana suatu partikel tersebut berhenti pada lokasi baru yang lebih optimal, maka posisi dan nilai objektif dari lokasi suatu partikel tersebut akan disimpan sebagai pBest (personal best). Selain itu, pada setiap iterasi, akan ada mekanisme untuk menyimpan lokasi global terbaik di antara sekelompok partikel ke dalam gBest (global best). Secara garis besar, algoritma PSO dapat dijabarkan dalam Gambar 3.

$$
\begin{aligned}
v_{i}=w * v_{i}+ & \operatorname{rand}(0,1) * c_{1} *\left(x_{p B e s t}-x_{i}\right) \\
& +\operatorname{rand}(0,1) * c_{2} *\left(x_{g B e s t}-x_{i}\right)
\end{aligned}
$$

di mana $v_{i}$ merupakan kecepatan dari partikel ke- $i$, $w$ merupakan parameter inertia weight, $c_{1}$ merupakan parameter cognitive factor, $c_{1}$ merupakan parameter social factor, $x_{i}$ adalah koordinat posisi dari partikel ke-i yang melambangkan kandidat solusi dari suatu permasalahan, $x_{p \text { Best }}$ adalah koordinat posisi dari $p$ Best, $x_{g B e s t}$ adalah koordinat posisi dari gBest.

Sebagai salah satu algoritma berbasis swarm intelligence yang ditemukan oleh Karaboga dan Basturk [29], ABC mengadopsi perilaku berkelompok dari lebah dalam mengumpulkan makanan. Mula-mula, algoritma ABC diawali dengan inisialisasi sumber makanan (alternatif solusi) yang berisikan variabel acak. Setelah sumber makanan ditentukan, algoritma akan memasuki tahap pertama, yaitu employed bees. Pada tahap ini, employed bees akan melakukan modifikasi terhadap alternatif solusi dengan mencari solusi lain di sekitarnya. Solusi tersebut kemudian akan diukur nilai objektifnya sebagai informasi yang akan dibagikan dengan onlooker bees melalui waggle dance yang dimodelkan melalui persamaan matematis yang dapat dilihat pada Persamaan (10). Pada tahap onlooker bees, solusi yang dihasilkan oleh employed bees akan dipilih secara acak dengan probabilitas tertentu. Onlooker bees kemudian akan memodifikasi kembali solusi tersebut berdasarkan informasi dari employed bees. Oleh karena onlooker bees memiliki kecenderungan untuk memilih alternatif solusi yang nilai objektifnya lebih baik, maka akan dihasilkan alternatif solusi yang dalam selang waktu tertentu tidak terpilih oleh onlooker bees. Pada kondisi ini, employed bees akan berubah menjadi scout bees untuk mencari alternatif solusi yang baru. Secara garis besar, algoritma ABC dapat dijabarkan dalam Gambar 4.

$n e w_{-} X_{i}=X_{i}+\operatorname{rand}(-1,1) *\left(X_{i}-X_{j}\right)$

di mana $X_{i}$ merupakan sumber makanan ke-i, dan $X_{j}$ merupakan sumber makanan ke-j yang dipilih secara acak.

Ditemukan pertama kali oleh Rao, Savsani dan Vakharia [30], TLBO mengambil inspirasi dari proses transfer ilmu di antara guru dan para 
muridnya di kelas. Ada jenis dua fase penyusun algoritma TLBO yaitu teacher phase dan learner phase. Di dalam teacher phase, seorang individu akan ditugaskan sebagai teacher $\left(X_{\text {teacher }}\right)$ apabila dia memiliki nilai terbaik diantara murid-murid (learner) yang lain. TLBO akan berusaha untuk memperbarui individu-individu yang ada dengan mengarahkan nilai rata-rata dari satu kelas $\left(X_{\text {mean }}\right)$ menuju ke arah $X_{\text {teacher }}$ Proses modifikasi solusi yang terjadi di dalam fase ini dimodelkan dalam Persamaan (11). Di dalam learner phase, transfer ilmu akan dilanjutkan dengan proses diskusi dan interaksi antara dua orang learner $\left(X_{i}\right.$ dan $\left.X_{j}\right)$ dengan dengan tujuan untuk meningkat nilai dari masing-masing individu. Proses modifikasi solusi yang terjadi di dalam fase ini dimodelkan dalam Persamaan (12). Dalam hal memperbaharui kualitas solusi dari individu, TLBO juga menerapkan konsep greedy selection. Secara garis besar, algoritma TLBO dapat dijabarkan dalam Gambar 5 .

$$
\begin{aligned}
& \text { new_ } X_{i}=X_{i}+\operatorname{rand}(0,1) *\left(X_{\text {teacher }}-\operatorname{round}[1+\right. \\
& \left.\operatorname{rand}(0,1)] * X_{\text {mean }}\right) \\
& \text { new_ } X_{i}= \\
& \left\{\begin{array}{lc}
X_{i}+\operatorname{rand}(0,1) *\left(X_{i}-X_{j}\right) & f\left(X_{i}\right)<f\left(X_{j}\right) \\
X_{i}+\operatorname{rand}(0,1) *\left(X_{j}-X_{i}\right) & \text { lainnya }
\end{array}\right.
\end{aligned}
$$

di mana $f\left(X_{i}\right)$ dan $f\left(X_{j}\right)$ merupakan nilai objektif dari masing-masing $X_{i}$ dan $X_{j}$.

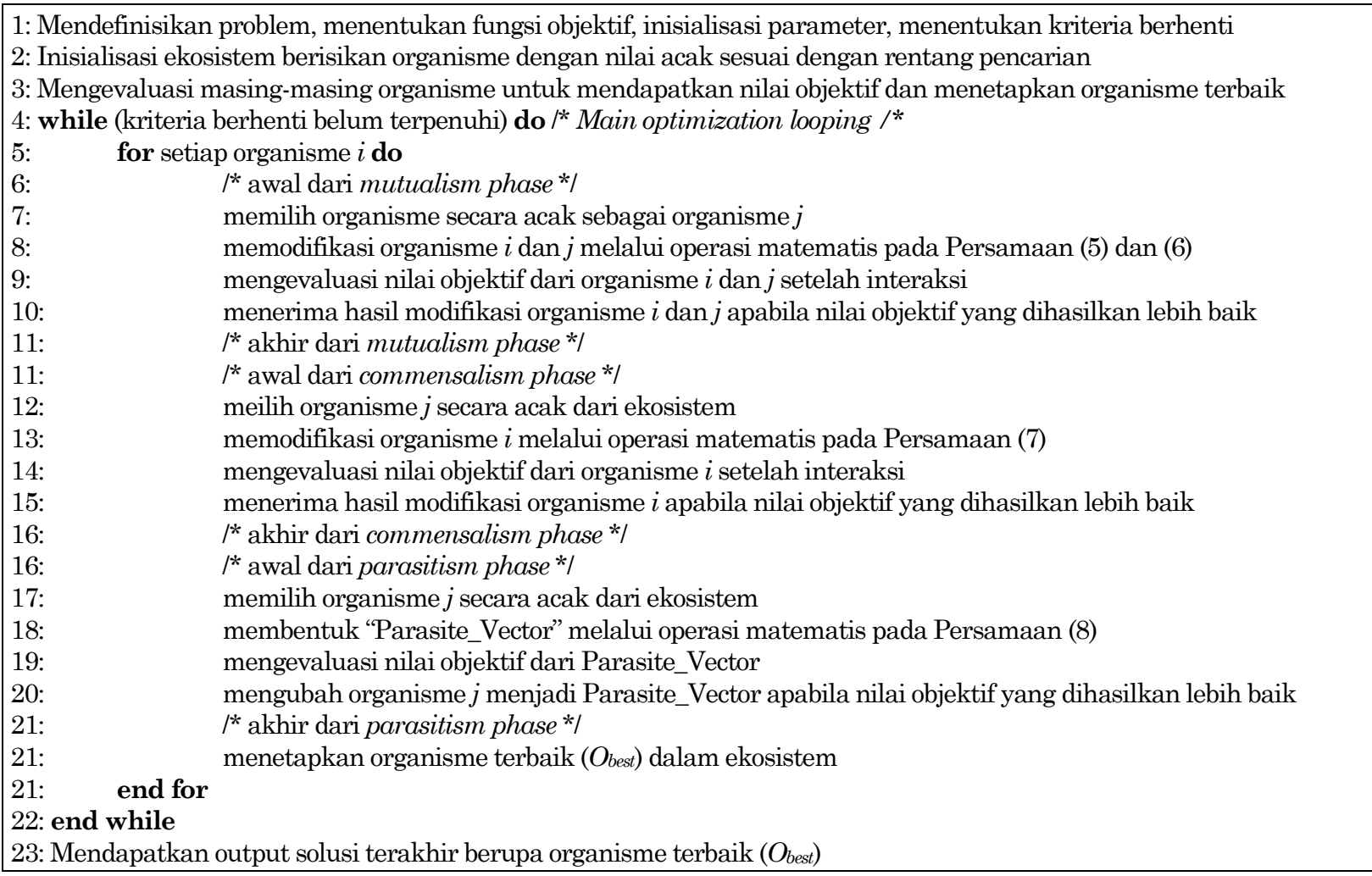

Gambar 2. Pseudo-code dari algoritma SOS

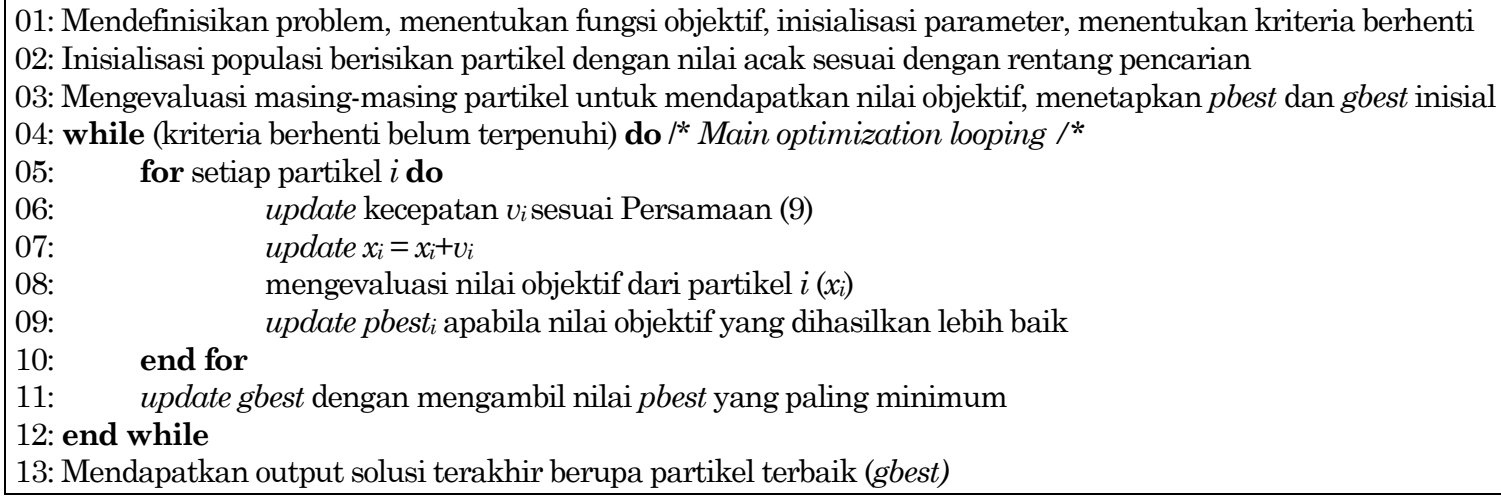

Gambar 3. Pseudo-code dari algoritma PSO 


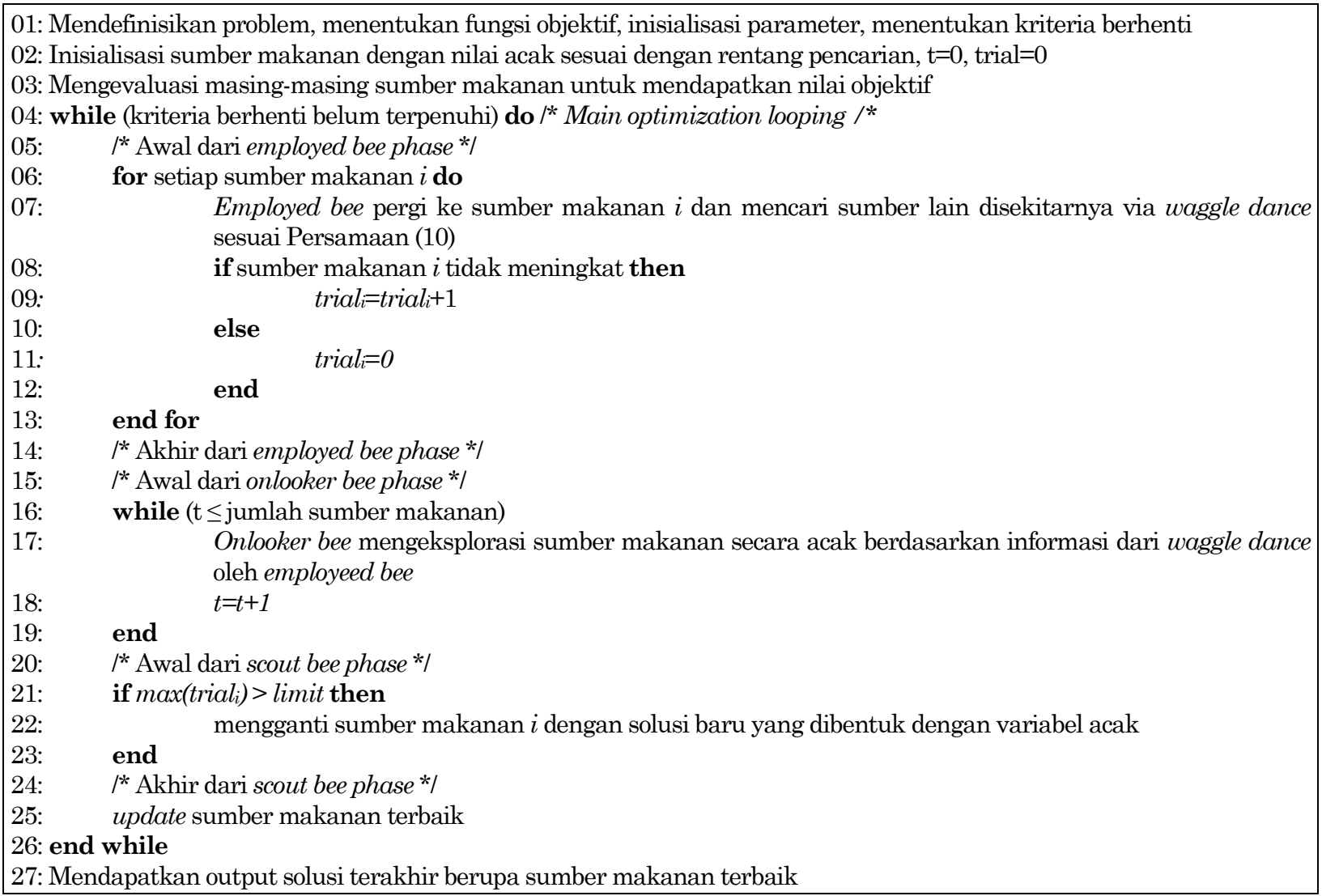

Gambar 4. Pseudo-code dari algoritma ABC

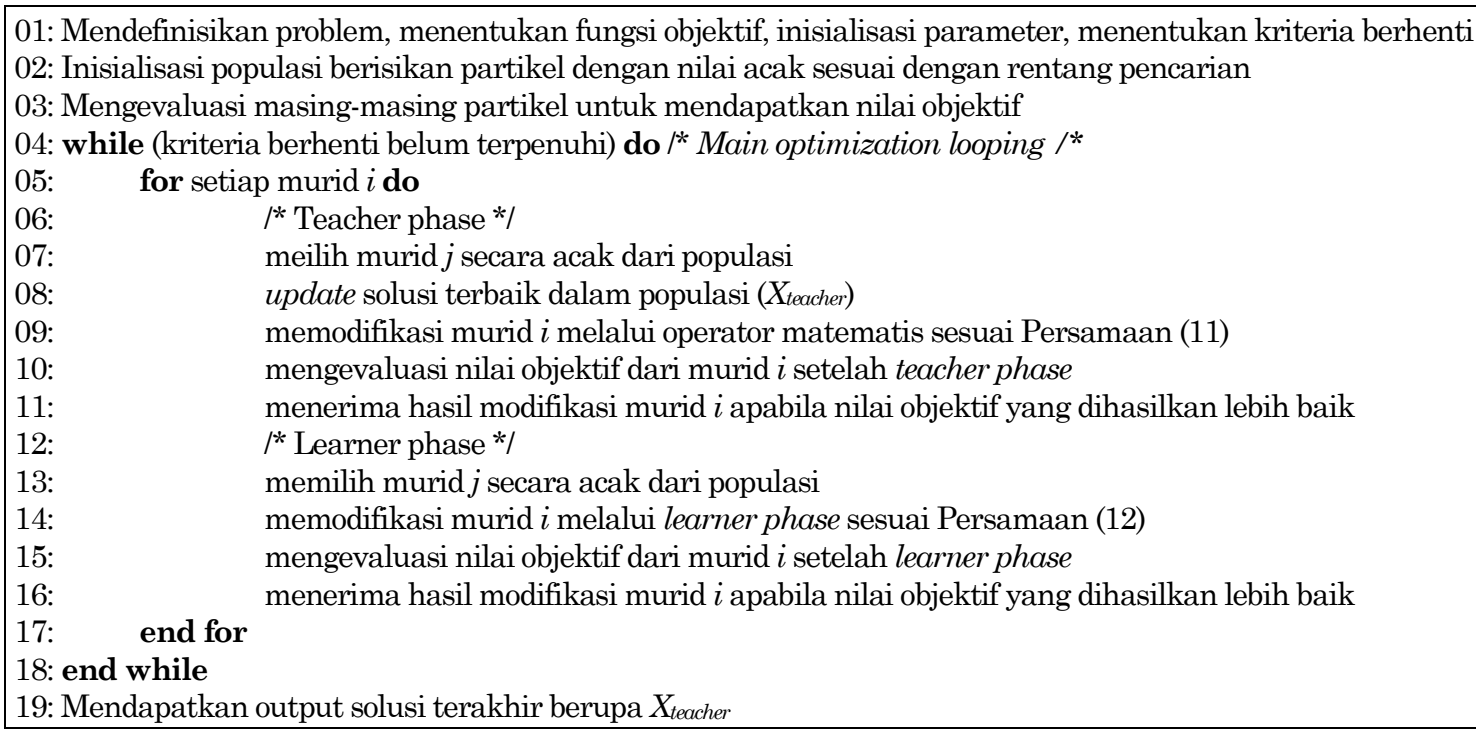

Gambar 5. Pseudo-code dari algoritma TLBO

Tabel 1. Transformasi solusi berbasis continuous menjadi permutasi

\begin{tabular}{lllllllll}
\hline Lokasi & 1 & 2 & 3 & 4 & 5 & 6 & 7 & 8 \\
\hline Solusi fasilitas berbasis continuous & 0,34 & 0,29 & 0,87 & 0,98 & 0,02 & 0,49 & 0,45 & 0,61 \\
Solusi fasilitas berbasis permutasi & 3 & 2 & 7 & 8 & 1 & 5 & 4 & 6 \\
\hline
\end{tabular}


Proses Optimasi Penentuan Tata Letak Fasilitas dengan Menggunakan Algoritma Metaheuristik

Proses optimasi penentuan tata letak fasilitas dari masing-masing algoritma metaheuristik terbagi menjadi 4 tahapan yaitu:

\section{Inisialisasi parameter}

Penentuan fungsi objektif serta informasi pendukung kasus tata letak fasilitas seperti jarak antar lokasi dan frekuensi perpindahan pekerja antar fasilitas harus didefinisikan dengan jelas di awal. Selain itu, setiap algoritma metaheuristik memiliki parameter yang harus ditentukan sebelum proses pencarian dimulai.

\section{Inisialisasi variabel solusi (populasi) secara acak dan evaluasi nilai objektif}

Masing-masing dari algoritma metaheuristik akan melakukan inisialisasi variabel solusi awal secara acak. Adapun variabel solusi yang dibentuk berupa angka permutasi yang menyatakan hubungan antara penempatan fasilitas dan lokasi. Ketiga algoritma yang digunakan dalam penelitian ini bersifat continuous, namun, solusi yang harus dihasilkan berupa angka permutasi. Oleh karena itu, dibutuhkan adaptasi terhadap solusi yang dihasilkan oleh metaheuristik. Penelitian ini mengembangkan prosedur untuk mengubah representasi solusi dari nilai berbasis continuous menjadi nilai berbasis urutan atau permutasi. Representasi tata letak fasilitas dibuat sesuai dengan nilai indeks terhadap nilai continuous yang diurutkan menurut urutan naik. Representasi solusi ini digunakan untuk memecahkan masalah penentuan tata letak fasilitas. Contoh proses transformasi solusi yang semula dari berbasis continuous diubah menjadi berbasis permutasi dapat diilustrasikan melalui Tabel 1. Setelah proses transformasi selesai, variabel solusi yang menandakan hubungan penempatan fasilitas terhadap lokasi akan dievaluasi nilai objektifnya.

\section{Menjalankan proses optimasi yang disimulasi- kan oleh algoritma metaheuristik}

Proses optimasi akan dilakukan secara berulangulang dengan prinsip tertentu sesuai dengan karakteristik pola pencarian masing-masing algoritma. Simulasi pencarian pada PSO dilakukan berdasarkan konsep pergerakan partikel yang mengacu pada pbest dan gbest. Simulasi pencarian pada ABC akan melibatkan employed bees, onlooker bees, dan scout bees dan penerimaan solusi baru diijinkan apabila solusi berikutnya menjadi lebih optimal. Simulasi pencarian pada TLBO akan melalui teacher phase dan learner phase dan penerimaan solusi baru diijinkan apabila solusi berikutnya menjadi lebih optimal. Simulasi pencarian pada SOS akan melibatkan mutualism phase, commensalism phase, dan parasitism phase dimana penerimaan solusi baru diijinkan apabila solusi berikutnya menjadi lebih optimal pada setiap fase.

\section{Kriteria berhenti}

Informasi penempatan tata letak fasilitas terhadap lokasi yang dibawa oleh populasi akan dilanjutkan ke proses optimasi pada generasi selanjutnya sampai kriteria berhenti terpenuhi.

\section{Hasil dan Pembahasan}

Penelitian ini akan menginvestigasi kemampuan SOS dalam menentukan tata letak fasilitas proyek konstruksi akan diselidiki dengan menggunakan dua studi kasus, di antaranya: (1) kasus tata letak 11 fasilitas yang diadopsi dari Li and Love [10] dan (2) kasus tata letak fasilitas yang diambil dari proyek konstruksi bangunan tinggi di Surabaya. Sebagai perbandingan, akan dilibatkan algoritmaalgoritma metaheuristik dasar yang lain seperti PSO, ABC, dan TLBO pada penelitian ini.

Sebanyak total 30 kali simulasi penyelesaian kasus optimasi akan dilakukan oleh setiap algoritma metaheuristik untuk menguji konsistensi. Total jarak tempuh pekerja terbaik yang didapatkan oleh setiap algoritma akan digunakan untuk mendapatkan nilai rata-rata, standar deviasi, terbaik dan terburuk. Parameter yang digunakan oleh setiap metode diatur pada Tabel 2. Masing-masing algoritma metaheuristik menggunakan jumlah populasi (Npop) dan jumlah iterasi maksimum (MaxIt) yang sama yaitu masing-masing 50 dan 25 .

\section{Studi Kasus 1: Problem Tata Letak 11 Fasilitas Proyek}

Pada kasus yang di adopsi dari Li dan Love [10], terdapat sejumlah 11 fasilitas dan 11 lokasi, seperti yang terlihat pada Gambar 6. Ada dua buah fasilitas yang memiliki lokasi yang permanen. Sementara itu, frekuensi perpindahan harian dan jarak antar lokasi dapat dilihat pada Tabel 3 dan Tabel 4. Fasilitas-fasilitas yang terdapat pada studi kasus ini diantara lain: (1) Site office (SO). (2) Falsework shop (FS). (3) Labor residence (LR). (4) Storeroom 1 (S1). (5) Storeroom 2 (S2). (6) Carpentry workshop (CW). (7) Reinforcement steel workshop (RW). (8) Side gate (SG), lokasi permanen. (9) Electrical, water, and utility control room (UR). (10) Concrete batch workshop (BW). (11) Main gate (MG), lokasi permanen.

Tabel 2. Pengaturan parameter untuk setiap algoritma metaheuristik

\begin{tabular}{llll}
\hline PSO & ABC & TLBO & SOS \\
\hline$c_{1}=2$ & & & \\
$c_{2}=2$ & Limit $=100$ & Npop $=50$ & Npop $=50$ \\
$w=0,4-0,9$ & Npop $=50$ & MaxIt $=25$ & MaxIt $=25$ \\
Npop $=50$ & MaxIt $=25$ & & \\
MaxIt $=25$ & & & \\
\hline
\end{tabular}


Tabel 5 mencatat hasil rata-rata, terbaik, terburuk, dan standar deviasi yang setelah simulasi dari masing-masing metode selesai dilakukan. Terlihat bahwa keempat algoritma dari masing-masing algoritma metaheuristik mampu menghasilkan nilai terbaik 12546 m. Namun, hanya SOS dan TLBO yang dapat menghasilkan nilai terbaik pada setiap perulangan simulasi ditunjukkan dari nilai rata-rata yang juga sama dengan nilai terbaik yaitu $12546 \mathrm{~m}$, dan oleh karena itu standar deviasinya juga bernilai 0 .

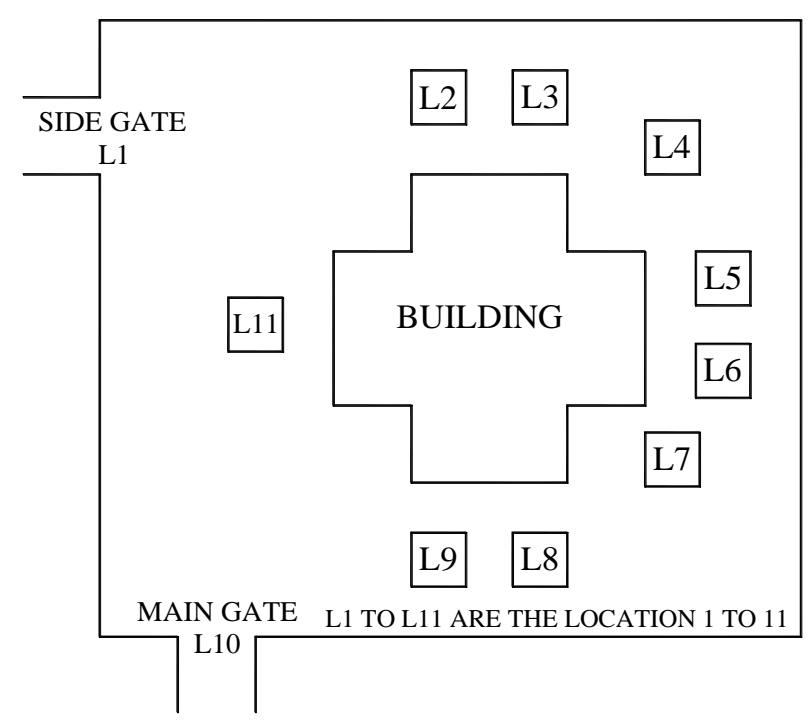

Gambar 6. Tata letak dari proyek pada studi kasus 1

Tabel 3. Matriks jarak antara lokasi pada studi kasus 1 (dalam satuan meter)

\begin{tabular}{lccccccccccc}
\hline & L1 & L2 & L3 & L4 & L5 & L6 & L7 & L8 & L9 & L10 & L11 \\
\hline L1 & - & 15 & 25 & 33 & 40 & 42 & 47 & 55 & 35 & 34 & 20 \\
L2 & & - & 10 & 18 & 25 & 27 & 32 & 42 & 50 & 45 & 35 \\
L3 & & & - & 8 & 15 & 17 & 22 & 32 & 52 & 55 & 45 \\
L4 & & & & - & 7 & 9 & 14 & 24 & 44 & 49 & 53 \\
L5 & & & & & - & 2 & 7 & 17 & 37 & 42 & 52 \\
L6 & & & & & & - & 5 & 15 & 35 & 40 & 50 \\
L7 & & & & & & & - & 10 & 30 & 35 & 40 \\
L8 & & & & & & & & - & 20 & 25 & 35 \\
L9 & & & & & & & & & - & 5 & 15 \\
L10 & & & & & & & & & - & 10 \\
L11 & & & & & & & & & & - \\
\hline
\end{tabular}

Tabel 4. Matriks frekuensi pergerakan pekerja antar fasilitas pada studi kasus 1

\begin{tabular}{|c|c|c|c|c|c|c|c|c|c|c|}
\hline & SO FS & LR & S1 & $\mathrm{S} 2$ & $\mathrm{CH}$ & $\mathbf{R}$ & & UR & BW & MG \\
\hline SO & -5 & 2 & 2 & 1 & 1 & 4 & & 2 & 9 & 1 \\
\hline FS & - & 2 & 5 & 1 & 2 & 7 & & 2 & 3 & 8 \\
\hline LR & & - & 7 & 4 & 4 & $\mathrm{~s}$ & & 5 & 6 & 5 \\
\hline S1 & & & - & 8 & 7 & $\varepsilon$ & & 8 & 5 & 1 \\
\hline S2 & & & & - & 3 & 4 & & 3 & 3 & 6 \\
\hline CW & & & & & - & 5 & & 4 & 7 & 5 \\
\hline RW & & & & & & . & & 6 & 3 & 2 \\
\hline SG & & & & & & & & 9 & 4 & 8 \\
\hline UR & & & & & & & & - & 5 & 3 \\
\hline BW & & & & & & & & & - & 5 \\
\hline MG & & & & & & & & & & - \\
\hline
\end{tabular}

Tabel 5. Nilai rata-rata, terbaik, terburuk, dan standar deviasi setelah 30 kali simulasi (dalam meter)

\begin{tabular}{lcccc}
\hline Metode & Rata-rata & Terbaik & Terburuk & Standar deviasi \\
\hline PSO & 12588,0 & 12546 & 12678 & 68,35 \\
ABC & 12642,2 & 12546 & 12904 & 110,93 \\
TLBO & 12546,0 & 12546 & 12546 & 0 \\
SOS & 12546,0 & 12546 & 12546 & 0 \\
\hline
\end{tabular}

Tabel 6. Penempatan fasilitas terhadap lokasi pada hasil usulan tata letak yang optimal

\begin{tabular}{lcccccc}
\hline Lokasi & 1 & 2 & 3 & 4 & 5 & 6 \\
Tata letak optimal & SG & UR & RW & LR & CW & S1 \\
\hline Lokasi & 7 & 8 & 9 & 10 & 11 & $\begin{array}{l}\text { Nilai } \\
\text { objektive } \\
\text { (meter) }\end{array}$ \\
& & & & & & \\
Tata letak optimal & S2 & BW & SO & MG & FS & 39199,6 \\
\hline
\end{tabular}

Algoritma dengan performa terburuk pada kasus ini adalah $\mathrm{ABC}$, dengan nilai rata-rata, standar deviasi, serta nilai terburuk yang lebih tinggi jika dibandingkan ketiga metode lainnya. Tabel 6 menunjukkan penempatan fasilitas pada lokasi menurut tata letak optimal yang didapatkan dari simulasi menggunakan algoritma metaheuristik.

\section{Studi Kasus 2: Problem Tata Letak Fasilitas Proyek Bangunan Bertingkat di Surabaya}

Penelitian ini mengadopsi denah tata letak salah satu proyek konstruksi bangunan bertingkat yang ada di Surabaya. Berdasarkan data fasilitas pada proyek tersebut, terdapat total 32 jenis fasilitas mula-mula. Namun, setelah dilakukan observasi lapangan secara langsung, tidak semua fasilitas sementara tersebut aktif digunakan. Di samping itu, ada beberapa fasilitas yang tidak mengalami pergerakan dan tidak berhubungan dengan proses pelaksanaan yang pada saat dilakukan observasi. Dalam penelitian ini, dilakukan pengeliminasian pada fasilitas-fasilitas sementara yang tidak aktif yang menyebabkan total fasilitas sementara berkurang menjadi 10 jenis yang akan digunakan untuk proses optimasi. Lokasi untuk penempatan fasilitas dapat dilihat pada Gambar 7. Fasilitasfasilitas tersebut antara lain: (1) Batching plant (BP). (2) Direksi keet (DK). (3) Workshop bekisting (WB). (4) Gate masuk (GM), ditempatkan permanen pada lokasi 4. (5) Pos jaga (PJ), ditempatkan permanen pada lokasi 5. (6) Fabrikasi GRC (FG). (7) Kantor kontraktor (KI). (8) Penyimpanan besi (SB). (9) Fabrikasi besi 1 (FB1). (10) Fabrikasi besi 2 (FB2).

Sementara itu, frekuensi perpindahan harian dan jarak antar lokasi dapat dilihat pada Tabel 7 dan Tabel 8. Jarak antara fasilitas sementara yang akan ditentukan bersifat reversible. Sebagai contoh, jarak antara batching plant dan direksi keet akan sama dengan jarak direksi keet ke batching plant. 


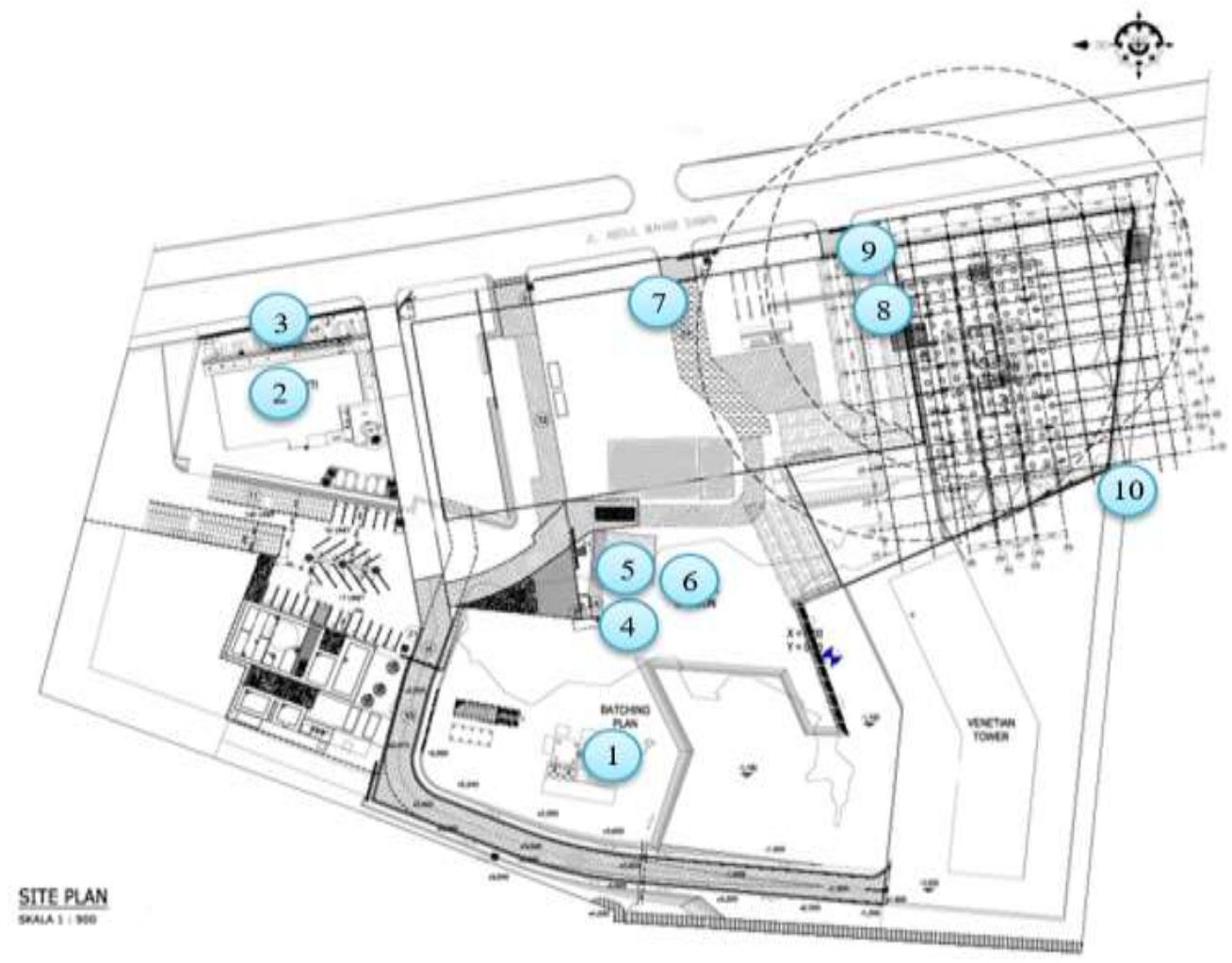

Gambar 7. Tata letak dari proyek pada studi kasus 2

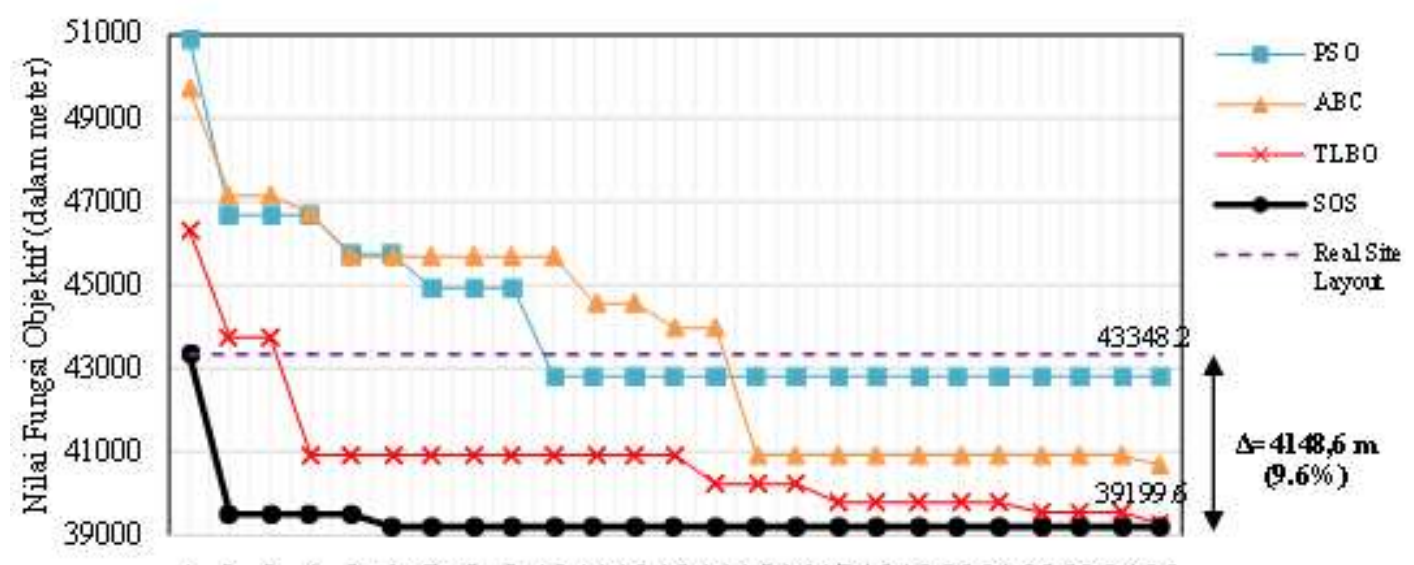

$123 \quad 344566788910111213141516171819202122232425$ Iterasi ke-

Gambar 8. Grafik perbandingan karakteristik konvergensi untuk setiap algoritma metaheuristik

Tabel 7. Matriks jarak antara lokasi pada studi kasus 2 (dalam satuan meter)

\begin{tabular}{|c|c|c|c|c|c|c|c|c|c|c|}
\hline & 1 & 2 & 3 & 4 & 5 & 6 & 7 & 8 & 9 & 10 \\
\hline 1 & - & 138,6 & 156,2 & 32,6 & 39,2 & 49,4 & 138,1 & 170,2 & 174,3 & 150,3 \\
\hline 2 & & - & 19,1 & 106,1 & 100,1 & 111,8 & 128,3 & 160,4 & 164,5 & 188,2 \\
\hline 3 & & & - & 125,1 & 119,2 & 130,8 & 111,7 & 143,8 & 147,9 & 207,3 \\
\hline 4 & & & & - & 12,3 & 22,6 & 111,3 & 143,3 & 147,4 & 123,4 \\
\hline 5 & & & & & - & 11,6 & 98,9 & 131 & 135,1 & 111,1 \\
\hline 6 & & & & & & - & 88,7 & 120,7 & 124,8 & 100,7 \\
\hline 7 & & & & & & & - & 32 & 36,2 & 104,1 \\
\hline 8 & & & & & & & & - & 9,3 & 41,9 \\
\hline 9 & & & & & & & & & - & 102,1 \\
\hline 10 & & & & & & & & & & - \\
\hline
\end{tabular}


Tabel 8. Matriks frekuensi pergerakan pekerja antar fasilitas pada studi kasus 2

\begin{tabular}{ccccccccccc}
\hline & BP & DK & WB & GM & PJ & FG & KI & SB & FB1 & FB2 \\
\hline BP & - & 10 & 8 & 9 & 3 & 9 & 0 & 0 & 0 & 0 \\
DK & & - & 8 & 12 & 8 & 9 & 11 & 5 & 0 & 1 \\
WB & & & - & 4 & 3 & 8 & 0 & 0 & 0 & 0 \\
GM & & & - & 6 & 15 & 10 & 10 & 8 & 5 \\
PJ & & & & - & 9 & 5 & 3 & 2 & 1 \\
FG & & & & & - & 0 & 0 & 0 & 0 \\
KI & & & & & & - & 7 & 7 & 10 \\
SB & & & & & & & - & 25 & 27 \\
FB1 & & & & & & & & - & 16 \\
FB2 & & & & & & & & & - \\
\hline
\end{tabular}

Tabel 9. Nilai rata-rata, terbaik, terburuk, dan standar deviasi setelah 30 kali simulasi (dalam meter)

\begin{tabular}{lcccc}
\hline \multicolumn{1}{c}{ Metode } & Rata-rata & Terbaik & Terburuk & $\begin{array}{c}\text { Standar } \\
\text { deviasi }\end{array}$ \\
\hline PSO & 41280,4 & 39199,6 & 46178,0 & 2484,8 \\
ABC & 40673,0 & 39199,6 & 45828,6 & 1836,4 \\
TLBO & 39302,3 & 39199,6 & 40235,0 & 236,8 \\
SOS & 39199,6 & 39199,6 & 39199,6 & 0 \\
\hline
\end{tabular}

Tabel 10. Perbandingan penempatan fasilitas terhadap lokasi proyek semula dan setelah dioptimasi oleh SOS

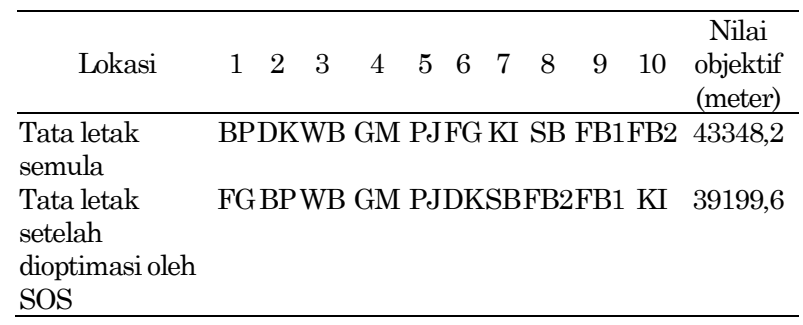

Tabel 9 mencatat hasil rata-rata, terbaik, terburuk, dan standar deviasi yang setelah simulasi dari masing-masing metode selesai dilakukan. Terlihat bahwa keempat algoritma dari masing-masing algoritma metaheuristik mampu menghasilkan nilai terbaik 39199,6 m. Namun, hanya SOS yang dapat menghasilkan nilai terbaik pada setiap perulangan simulasi ditunjukkan dari nilai rata-rata yang juga sama dengan nilai terbaik yaitu 39199,6 m, dan oleh karena itu standar deviasinya juga bernilai 0. Algoritma dengan performa terburuk pada kasus ini adalah PSO, dengan nilai rata-rata, standar deviasi, serta nilai terburuk yang lebih tinggi jika disbandingkan ketiga metode lainnya. Disamping itu, SOS menghasilkan nilai objektif yang lebih kecil 4148,6 meter dibandingkan dengan nilai objektif dari tata letak fasilitas proyek semula seperti yang terlihat pada Tabel 10. Hal ini membuat algoritma SOS dapat menghasilkan alternatif solusi 9,6\% lebih baik dibandingkan dengan tata letak fasilitas proyek semula.

Selain itu, analisa karakteristik konvergensi dari masing-masing metode metaheuristik dilakukan guna mempelajari seberapa cepat suatu metode dalam menemukan solusi optimal. Gambar 8 menunjukkan perbandingan perubahan nilai objektif pada setiap iterasi, dari iterasi pertama hingga iterasi terakhir, untuk masing-masing metode. Terlihat pada simulasi tersebut, SOS mampu menemukan solusi optimal pada iterasi ke-7. Dapat disimpulkan bahwa metode SOS mampu mencapai titik konvergen lebih cepat dan lebih optimal jika dibandingkan dengan ketiga metode lainnya.

\section{Simpulan}

Penelitian ini mengimplementasikan SOS dalam penentuan tata letak fasilitas yang didasarkan kepada jarak tempuh pekerja proyek konstruksi. Dua buah studi kasus optimasi penentuan tata letak fasilitas proyek diadopsi untuk menguji performa dari SOS, diantaranya: problem tata letak 11 fasilitas proyek dan problem tata letak fasilitas proyek bangunan bertingkat di Surabaya. Dalam kesempatan ini, PSO, ABC, dan TLBO ditunjuk sebagai pembanding. Analisa hasil menunjukkan bahwa SOS memiliki akurasi pencarian solusi yang tinggi pada setiap kasus bila dibandingkan dengan algoritma lainnya. Hal ini terbukti dari solusi yang dihasilkan oleh SOS selalu menjadi yang paling optimal. Di sisi lain, SOS mampu secara konsisten menghasilkan solusi optimal bila dibandingkan dengan algoritma lainnya. SOS mampu menghasilkan nilai rata-rata dan standar deviasi terkecil di antara algoritma-algoritma lainnya dari hasil 30 kali perulangan pada masing-masing kasus. Algoritma metaheuristik yang baik biasanya memiliki kemampuan mencari area pencarian global baru yang berpotensi memiliki solusi optimal (dikenal dengan kemampuan eksplorasi) serta kemampuan menyelidiki solusi lokal yang terbaik dalam area pencarian tertentu (dikenal dengan kemampuan eksploitasi). Keseimbangan skema pencarian SOS yang terbagi menjadi kemampuan eksplorasi ( $m u$ tualism phase dan commensalism phase) serta kemampuan eksploitasi (parasitism phase) mampu membuat SOS unggul dibanding metode metaheuristik lainnya. Sebagai tambahan, melalui parasitism phase, SOS juga mampu untuk menghilangkan solusi inferior. Hal ini menjadikan SOS sebagai salah satu alternatif metode yang cukup potensial untuk menghadapi berbagai permasalahan di bidang tata letak fasilitas proyek.

\section{Daftar Pustaka}

1. Adrian, A. M., Utamima, A., and Wang, K.-J., A Comparative Study of GA, PSO and ACO for Solving Construction Site Layout Optimization, KSCE Journal of Civil Engineering, 19(3), 2015, pp. 520-527.

2. Tommelein, I., Levitt, R., and Hayes-Roth, B., SightPlan Model for Site Layout, Journal of Construction Engineering and Management, 118(4), 1992, pp. 749-766. 
3. Simmons, D. M., Single Row Space Allocation: An Ordering Algorithm, Operations Research, 17(5), 1969, pp. 812-826.

4. Picard, J.-C. and Queyranne, M., On the OneDimensional Space Allocation Problem, Operations Research, 29(2), 1981, pp. 371-391.

5. Love, R. F. and Wong, J. Y., On Solving a Single Row Space Allocation Problem with Integer Programming, INFOR: Information Systems and Operational Research, 14(2), 1976, pp. 139-143.

6. Ravi Kumar, K., Hadjinicola, G. C., and Lin, T.1., A Heuristic Procedure for the Single-Row Facility Layout Problem, European Journal of Operational Research, 87(1), 1995, pp. 65-73.

7. Holland, J. H., Adaptation in Natural and Artificial Systems, University of Michigan Press, 1975.

8. Kennedy, J. and Eberhart, R., Particle Swarm Optimization, Proceedings of IEEE International Conference on Neural Networks, 1995, pp. 1942-1948.

9. Dorigo, M., Maniezzo, V., and Colorni, A., Ant System: Optimization by a Colony of Cooperating Agents, IEEE Transactions on Systems, Man, and Cybernetics, Part B (Cybernetics), 26(1), 1996, pp. 29-41.

10. Li, H. and Love, P. E. D., Site-Level Facilities Layout Using Genetic Algorithms, Journal of Computing in Civil Engineering, 12(4), 1998, pp. 227-231.

11. Zouein, P., Harmanani, H., and Hajar, A., Genetic Algorithm for Solving Site Layout Problem with Unequal-Size and Constrained Facilities, Journal of Computing in Civil Engineering, 16(2), 2002, pp. 143-151.

12. Lee, K.-Y., Roh, M.-I., and Jeong, H.-S., An Improved Genetic Algorithm for Multi-Floor Facility Layout Problems Having Inner Structure Walls and Passages, Computers \& Operations Research, 32(4), 2005, pp. 879-899.

13. Önüt, S., Tuzkaya, U. R., and Doğaç, B., A Particle Swarm Optimization Algorithm for the Multiple-Level Warehouse Layout Design Problem, Computers \& Industrial Engineering, 54(4), 2008, pp. 783-799.

14. Zhang, H. and Wang, J. Y., Particle Swarm Optimization for Construction Site UnequalArea Layout, Journal of Construction Engineering and Management, 134(9), 2008, pp. 739748.

15. Lam, K. C., Ning, X., and Ng, T., The Application of the Ant Colony Optimization Algorithm to the Construction Site Layout Planning Problem, Construction Management and Economics, 25(4), 2007, pp. 359-374.

16. Liang, L. Y. and Chao, W. C., The Strategies of Tabu Search Technique for Facility Layout Optimization, Automation in Construction, 17(6), 2008, pp. 657-669.
17. Yahya, M. and Saka, M. P., Construction Site Layout Planning using Multi-objective Artificial Bee Colony Algorithm with Levy flights, Automation in Construction, 38, 2014, pp. 14-29.

18. Setiawan, I. L. and Palit, H. C., Perbandingan Kombinasi Genetic Algorithm-Simulated Annealing dengan Particle Swarm Optimization pada Permasalahan Tata Letak Fasilitas, Jurnal Teknik Industri, 12(2), 2010, pp. pp. 119124.

19. Mak, K. L., Wong, Y. S., and Chan, F. T. S., A Genetic Algorithm for Facility Layout Problems, Computer Integrated Manufacturing Systems, 11(1-2), 1998, pp. 113-127.

20. Prayogo, D., An Innovative Parameter-Free Symbiotic Organisms Search (SOS) for Solving Construction-Engineering Problems, 2015, PhD Thesis, Department of Construction Engineering, National Taiwan University of Science and Technology.

21. Cheng, M.-Y., Firdausi, P. M., and Prayogo, D., High-performance concrete compressive strength prediction using Genetic Weighted Pyramid Operation Tree (GWPOT), Engineering Applications of Artificial Intelligence, 29, 2014, pp. 104-113.

22. Cheng, M.-Y., Prayogo, D., and Tran, D.-H., Optimizing Multiple-Resources Leveling in Multiple Projects Using Discrete Symbiotic Organisms Search, Journal of Computing in Civil Engineering, 30(3), 2016, pp. 04015036.

23. Prayogo, D., Cheng, M.-Y., and Prayogo, H., A Novel Implementation of Nature-inspired Optimization for Civil Engineering: A Comparative Study of Symbiotic Organisms Search, Civil Engineering Dimension, 19(1), 2017, pp. 36-43.

24. Tran, D.-H., Cheng, M.-Y., and Prayogo, D., A Novel Multiple Objective Symbiotic Organisms Search (MOSOS) for Time-cost-labor Utilization Tradeoff Problem, Knowledge-Based Systems, 94, 2016, pp. 132-145.

25. Cheng, M.-Y., Chiu, C.-K., Chiu, Y.-F., Wu, Y.W., Syu, Z.-L., Prayogo, D., and Lin, C.-H., SOS Optimization Model for Bridge Life Cycle Risk Evaluation and Maintenance Strategies, Journal of the Chinese Institute of Civil and Hydraulic Engineering, 26(4), 2014, pp. 293-308.

26. Cheng, M.-Y. and Prayogo, D., Modeling the Permanent Deformation Behavior of Asphalt Mixtures using a Novel Hybrid Computational Intelligence, ISARC 2016 - 33rd International Symposium on Automation and Robotics in Construction, Auburn, USA, 2016, pp. 10091015. International Association for Automation and Robotics in Construction.

27. Koopmans, T. and Beckmann, M., Assignment Problems and the Location of Economic Activities, Econometrica, 25(1), 1957, pp. 53-76. 
28. Loiola, E. M., de Abreu, N. M. M., BoaventuraNetto, P. O., Hahn, P., and Querido, T., A survey for the Quadratic Assignment Problem, European Journal of Operational Research, 176(2), 2007, pp. 657-690.

29. Karaboga, D. and Basturk, B., A Powerful and Efficient Algorithm for Numerical Function Optimization: Artificial Bee Colony (ABC) Algo- rithm, Journal of Global Optimization, 39(3), 2007, pp. 459-471.

30. Rao, R. V., Savsani, V. J., and Vakharia, D. P., Teaching-learning-based Optimization: A Novel Method for Constrained Mechanical Design Optimization Problems, Computer-Aided Design, 43(3), 2011, pp. 303-315. 